University of Nebraska - Lincoln

DigitalCommons@University of Nebraska - Lincoln

Papers in the Earth and Atmospheric Sciences

Earth and Atmospheric Sciences, Department

February 2007

\title{
Evaluating climatic and non-climatic influences on ion chemistry in natural and man-made lakes of Nebraska, USA
}

D. M. Bennett

University of Nebraska-Lincoln

Sherilyn C. Fritz

University of Nebraska-Lincoln, sfritz2@unl.edu

John C. Holz

University of Nebraska-Lincoln, jholz1@unl.edu

Aris A. Holz

University of Nebraska-Lincoln, aholz2@unl.edu

Vitaly A. Zlotnik

University of Nebraska-Lincoln, vzlotnik1@unl.edu

Follow this and additional works at: https://digitalcommons.unl.edu/geosciencefacpub

Part of the Earth Sciences Commons

Bennett, D. M.; Fritz, Sherilyn C.; Holz, John C.; Holz, Aris A.; and Zlotnik, Vitaly A., "Evaluating climatic and non-climatic influences on ion chemistry in natural and man-made lakes of Nebraska, USA" (2007).

Papers in the Earth and Atmospheric Sciences. 15.

https://digitalcommons.unl.edu/geosciencefacpub/15

This Article is brought to you for free and open access by the Earth and Atmospheric Sciences, Department of at DigitalCommons@University of Nebraska - Lincoln. It has been accepted for inclusion in Papers in the Earth and Atmospheric Sciences by an authorized administrator of DigitalCommons@University of Nebraska - Lincoln. 
Published in Hydrobiologia: The International Journal of Aquatic Sciences 591 (2007), pp. 103-115;

doi 10.1007/s10750-007-0798-z Copyright (C 2007 Springer Science+Business Media B.V. Used by permission. http://www.springerlink.com/content/100271/

\title{
Evaluating climatic and non-climatic influences on ion chemistry in natural and man-made lakes of Nebraska, USA
}

\author{
D. M. Bennett ${ }^{1}$, S. C. Fritz ${ }^{1, *}$, J. C. Holz ${ }^{2}$, A. A. Holz ${ }^{2}$, and V. A. Zlotnik ${ }^{1}$ \\ (1) Department of Geosciences, University of Nebraska, Lincoln, NE 68588-0340, USA \\ (2) School of Natural Resources, University of Nebraska, Lincoln, NE 68583-0814, USA \\ * Correspondence — Sherilyn C. Fritz, email sfritz2@unl.edu
}

\begin{abstract}
Conductivity and major ion chemistry data were analyzed for a suite of Nebraska (USA) natural lakes, reservoirs, sand pits, and barrow pits to evaluate the magnitude of climatic versus non-climatic influence on ionic concentration and composition. In both natural lakes and sand and barrow pits, conductivity is positively related to longitude and reflects decreasing effective moisture from east to west. Reservoirs showed no relationship between lake conductivity and location, probably because the reservoirs are very strongly influenced by groundwater and surface water inflow and have shorter residence times relative to the other lake types. At smaller spatial scales, conductivity among natural lakes is variable. Lakes that are at low elevation within a groundwater flow system were fresh, because of substantial input of fresh groundwater. In contrast, lakes at high elevation exhibited a wide range of conductivity, probably because of differences in the degree of connection to groundwater and surface to volume ratio impacts on evaporation rates. Differences also were evident among natural lakes in terms of their response to seasonal changes in precip-
\end{abstract}

itation. Sub-saline and saline lakes showed more seasonal variation in conductivity than freshwater lakes, and lakes in the more arid part of the state showed larger responses to precipitation change than those in areas to the east that receive higher precipitation.

Keywords: limnology, climate, conductivity, saline lakes, reservoirs

\section{Introduction}

Climate is a primary control on the chemistry of lakes via its influence on the hydrologic cycle, thermal structure, catchment weathering, and erosion. In arid, semi-arid, and sub-humid regions changes in the balance between precipitation and evaporation can produce distinct changes in ionic concentration and composition, particularly in lakes without a surface outlet and where groundwater is not a major component of the water budget (Fritz \& Saros, 2005). In North America, several synoptic surveys have evaluated climatic influences on lacustrine chemistry across large areas of the mid-continent (Gorham et al., 1983; Last, 1992) or on a smaller regional scale (Gos- 
selin, 1997; Schindler et al., 1996; Winter, 1986; McCarraher \& Bruce, 1977).

Topographic and hydrologic position within a regional groundwater flow system can affect the gain and loss of water and solutes via groundwater connections with neighboring basins at higher or lower elevation and thereby influence lake response to climate (Webster et al., 2000). The degree of hydrologic connectivity between lakes and groundwater is influenced by the hydrologic permeability of the surface deposits and has particularly strong impacts on ionic concentration and composition (Kratz et al., 1997). Several studies in western Nebraska have demonstrated the importance of these sorts of non-climatic influences on lake water chemistry (LaBaugh, 1986; Winter, 1986; Gosselin et al., 1994; Gosselin, 1997; Loope et al., 1995; Mason et al., 1997).

Prior studies of climatic and non-climatic influences on Nebraska lake chemistry have been conducted on a small group of natural lakes in the westernmost part of the state, where the climate is semi-arid and many lakes are saline $\left(>3 \mathrm{~g} \mathrm{l}^{-1}\right)$. Here we evaluate climatic and non-climatic influ- ences on ionic concentration and composition using a much larger database of lakes that span the entire state of Nebraska from east to west (Figure 1). The lakes include freshwater to saline natural lakes, as well as reservoirs, sand pits, and barrow pits. In most cases, we have at least one field season of monthly data spanning the summer (MJJAS) to assess the extent of seasonal water-chemistry variation. We also intensively sampled nearly all lakes in a $15 \times 15 \mathrm{~km}^{2}$ area of western Nebraska (Crescent Lake National Wildlife Refuge) to investigate the role of elevation and groundwater in affecting lake ionic concentration within a localized area.

\section{Study area}

Climate, soils, vegetation, and landforms vary considerably across Nebraska. The urban centers and arable agriculture of the eastern part of the state give way to small rural communities in the central and western portions of the state, where ranches of thousands of acres are used for grazing. Two major physiographic divisions, or natural regions,

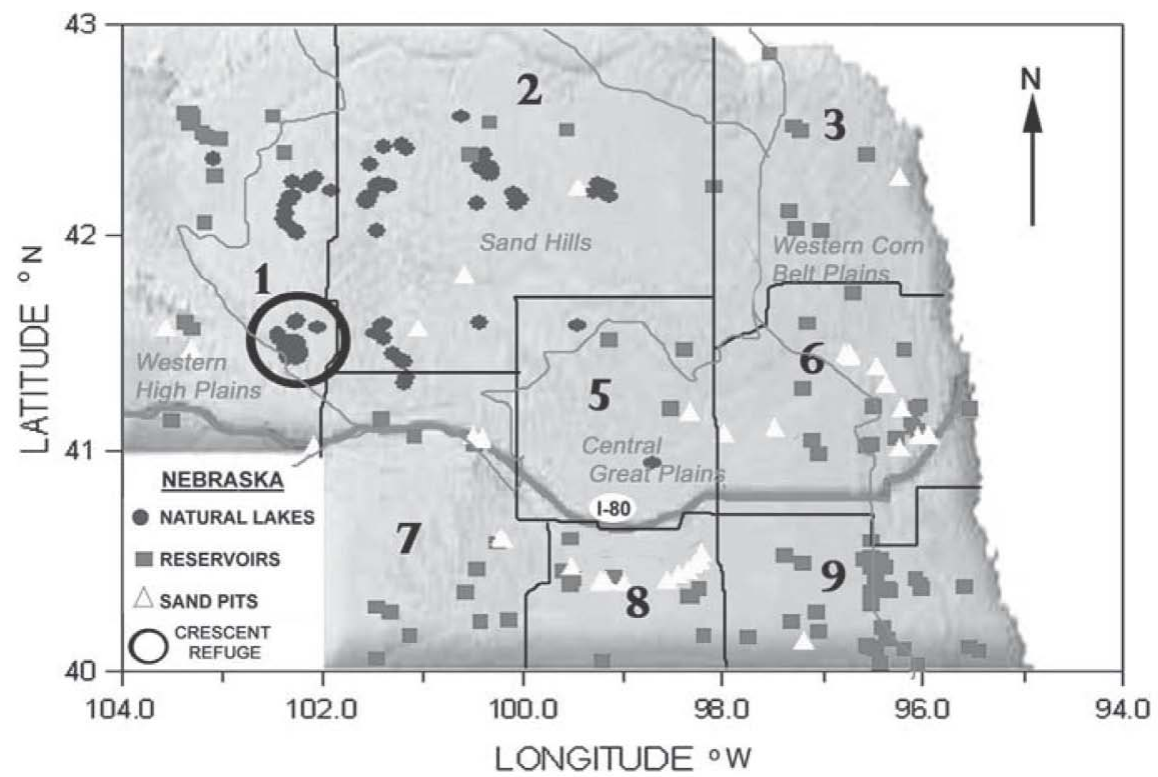

Figure 1 Lake sites in Nebraska. Numbers represent Nebraska climatic divisions (1-Panhandle, 2-North Central, 3-Northeast, 5Central, 6-East Central, 7-Southwest, 8-South Central, 9-Southeast). No lakes were sampled in climate division 4. Also shown are the major physiographic subdivisions of the Great Plains within Nebraska and the Crescent Lake National Wildlife Refuge, where the intensive sampling of natural lakes was carried out (see text) 
are represented in Nebraska. They are the Central Lowland and the Great Plains, both of which are subdivisions of the Interior Plains of North America. The eastern fifth of Nebraska is in the Central Lowland, and the remainder of the state forms part of the Great Plains. The Great Plains region is divided into four distinct areas based on topography and surficial geology: the High Plains, the Sand Hills, the Loess Hills and Canyons, and the Loess Plains. Grasslands covered about $98 \%$ of the state at the time of settlement in the late 19th century; trees are restricted to river valleys and some of the higher tablelands in the west.

Nebraska is divided into eight climatic divisions (Figure 1) (data based on NOAA/NCDC Climate Division map). It has a continental climate, with mean January temperatures that range from -7 to $-2{ }^{\circ} \mathrm{C}$ southwest to northeast, and mean July temperatures across the state of $\sim 23^{\circ} \mathrm{C}$. Precipitation in the northwest averages about 360 $\mathrm{mm}$ annually and increases to more than 860 $\mathrm{mm}$ in the southeast. Along the 100th meridian, which bisects the state, annual precipitation averages $\sim 500 \mathrm{~mm}$. The majority (50-75\%) of precipitation falls during summer months (MJJA), and the west to east annual precipitation gradient primarily reflects summer season precipitation; winter precipitation shows more limited spatial variation (Wilhite \& Hubbard, 1998). From 2000 to 2004, Nebraska was in major drought; June 2002 was the driest June on record (1895-2004), with particularly severe drought in the western part of the state.

Nebraska sits above the High Plains Aquifer, a large groundwater reservoir that extends under eight states in the central and southern Great Plains. Approximately 65\% of the High Plains Aquifer underlies the Nebraska Sand Hills (Bleed \& Flowerday, 1998). The extent to which this large groundwater system influences individual Sand Hills lakes apparently depends on topography, groundwater recharge rates, and hydraulic conductivity (Winter, 1986; Loope et al., 1995).

\section{Regional lakes}

Nebraska has more than 2000 natural lakes, as well as hundreds of man-made lakes, including reservoirs, sand pits, and barrow pits. The lakes range from less than a few hectares to 35,700 ha in area. The natural lakes of the Sand Hills region are located in an unglaciated part of the north-central United States (Winter, 1986). They are generally shallow, with a maximum depth typically less than $2 \mathrm{~m}$, and isothermal during the open-water season, because of frequent and intense winds. Some western lakes are playas, but the majority contain water throughout the year. In contrast, reservoirs and sand pits are usually deep, with water depths of up to $32 \mathrm{~m}$. The majority of Nebraska's reservoirs were built in the 1950-1970s, while sand pits and barrow pits were formed in the 1960s during years of major highway construction.

\section{Methods}

More than 250 natural lakes, sand pits and reservoirs $\left(43.10-40.03^{\circ} \mathrm{N}, 103.93-95.72{ }^{\circ} \mathrm{W}\right)$ in $\mathrm{Ne}-$ braska were sampled for water chemistry and other limnological data. Lakes were chosen to cover a wide range of limnological and environmental conditions (Table 1). The water bodies used for this study include 86 natural lakes, located mostly in the Sand Hills region, 104 reservoirs, and 60 sand and barrow pits.

The University of Nebraska-Lincoln (UNL) and the Nebraska Department of Environmental Quality (NDEQ) collected water samples and made field measurements in regional lakes during summer months (MJJAS) from 1989 to 2004. Different suites of lakes were sampled in individual years, but most lakes were sampled during several years within this interval. Water samples were drawn from the epilimnion (at about $0.5 \mathrm{~m}$ depth) monthly from May through September at the deepest location of the lake. From monthly samples, yearly means were calculated. In addition to surface water samples, conductivity, salinity, dissolved oxygen (DO), temperature and $\mathrm{pH}$ were measured at $0.5 \mathrm{~m}$ depth intervals with a multiprobe and surveyor (Model 4a, Hydrolab, Austin, TX). Turbidity was measured in the field using a field turbidimeter (Model 2100P, Hach, Loveland, $\mathrm{CO})$. Major ion chemistry is available only from 29 natural lakes.

In 2004, an additional 33 lakes and ponds were sampled in Crescent Lake National Wildlife Ref- 
Table 1 Mean, median, standard deviation, and ranges for major environmental data for sampled sites:

(A) Natural lakes, (B) Reservoirs, (C) Sand pits and Barrow pits

\begin{tabular}{|c|c|c|c|c|c|c|}
\hline Environmental variable & $N$ & Mean & Median & Minimum & Maximum & Standard deviation \\
\hline \multicolumn{7}{|l|}{$(A)$} \\
\hline Maximum depth (m) & 86 & 1.33 & 1.20 & 0.50 & 2.97 & 0.53 \\
\hline Alk. (mg/l $\left.\mathrm{CaCO}_{3}\right)$ & 86 & $3,151.90$ & 308.17 & 83.60 & $59,280.00$ & $8,847.86$ \\
\hline Cond. $(\mu \mathrm{S} / \mathrm{cm})$ & 86 & $4,526.59$ & 585.65 & 179.96 & $61,412.20$ & $10,697.13$ \\
\hline $\mathrm{pH}$ & 86 & 9.08 & 9.07 & 8.10 & 10.34 & 0.54 \\
\hline Salinity (g/l) & 43 & 5.59 & 0.83 & 0.08 & 126.85 & 19.75 \\
\hline $\mathrm{TN}(\mu \mathrm{g} / \mathrm{l})$ & 86 & $7,169.56$ & $4,836.81$ & 46.04 & $51,488.59$ & $7,891.83$ \\
\hline $\mathrm{TP}(\mu \mathrm{g} / \mathrm{L})$ & 86 & 547.03 & 319.91 & 6.04 & $3,575.52$ & 654.06 \\
\hline $\mathrm{N}: \mathrm{P}$ ratio & 86 & 24.55 & 15.62 & 2.45 & 181.98 & 25.86 \\
\hline Chl. a $(\mu \mathrm{g} / \mathrm{L})$ & 86 & 66.47 & 31.86 & 0.09 & 452.78 & 90.41 \\
\hline Turbidity (NTUs) & 83 & 54.40 & 22.57 & 2.80 & 385.60 & 79.81 \\
\hline \multicolumn{7}{|l|}{ (B) } \\
\hline Maximum depth (m) & 101 & 5.02 & 3.96 & 0.48 & 32.79 & 12.13 \\
\hline Alk. $\left.(\mathrm{mg} / \mathrm{l} \mathrm{CaCO})_{3}\right)$ & 104 & 157.00 & 153.72 & 32.45 & 367.00 & 70.88 \\
\hline Cond. $(\mu \mathrm{S} / \mathrm{cm})$ & 104 & 568.80 & 389.65 & 94.74 & $9,847.30$ & $1,620.09$ \\
\hline $\mathrm{pH}$ & 104 & 8.45 & 8.48 & 7.45 & 9.65 & 10.69 \\
\hline Salinity (g/l) & 40 & 0.31 & 0.14 & 0.04 & 5.57 & 7.33 \\
\hline $\mathrm{TN}(\mu \mathrm{g} / \mathrm{l})$ & 104 & $1,457.89$ & $1,098.70$ & 190.00 & $8,285.27$ & $1,230.46$ \\
\hline $\mathrm{TP}(\mu \mathrm{g} / 1)$ & 104 & 245.31 & 111.02 & 6.67 & $2,180.80$ & 390.73 \\
\hline $\mathrm{N}: \mathrm{P}$ ratio & 104 & 10.85 & 10.16 & 0.91 & 40.50 & 12.85 \\
\hline Chl. a $(\mu \mathrm{g} / 1)$ & 104 & 23.15 & 18.05 & 0.72 & 109.38 & 24.59 \\
\hline Turbidity (NTUs) & 60 & 143.42 & 35.72 & 3.44 & $1,163.20$ & 249.63 \\
\hline \multicolumn{7}{|l|}{ (C) } \\
\hline Maximum depth (m) & 53 & 5.37 & 4.68 & 1.14 & 10.02 & 2.50 \\
\hline Alk. (mg/l $\left.\mathrm{CaCO}_{3}\right)$ & 60 & 153.13 & 141.69 & 95.19 & 327.50 & 43.72 \\
\hline Cond. $(\mu \mathrm{S} / \mathrm{cm})$ & 60 & 685.44 & 546.07 & 216.75 & $2,260.80$ & 417.31 \\
\hline $\mathrm{pH}$ & 60 & 8.54 & 8.65 & 6.80 & 9.78 & 0.60 \\
\hline Salinity (g/l) & 35 & 1.08 & 0.28 & 0.11 & 24.79 & 4.13 \\
\hline $\mathrm{TN}(\mu \mathrm{g} / \mathrm{l})$ & 60 & 970.25 & 675.22 & 370.18 & $5,347.75$ & 865.26 \\
\hline $\mathrm{TP}(\mu \mathrm{g} / \mathrm{l})$ & 60 & 75.61 & 50.22 & 11.80 & 572.80 & 96.98 \\
\hline $\mathrm{N}: \mathrm{P}$ ratio & 59 & 28.79 & 17.78 & 1.06 & 150.04 & 29.45 \\
\hline Chl. a $(\mu \mathrm{g} / 1)$ & 49 & 24.85 & 19.92 & 3.44 & 117.02 & 22.83 \\
\hline Turbidity (NTUs) & 49 & 9.98 & 5.25 & 1.38 & 93.32 & 15.70 \\
\hline
\end{tabular}

uge to evaluate spatial heterogeneity of water chemistry within natural lakes in a restricted geographic area. Samples were analyzed for selected field parameters (depth, $\mathrm{pH}$, temperature and conductivity), and alkalinity was measured in the laboratory. Ten of the lakes also were analyzed for total dissolved solids (TDS) and major ions (Na, K, $\mathrm{Ca}, \mathrm{Mg}, \mathrm{Cl}, \mathrm{SO}_{4}, \mathrm{Br}$, and $\mathrm{F}$ ).

A principal components analysis (PCA) was carried out on environmental data from 63 natural lakes, reservoirs, and sand pits that had a full complement of chemical and geographic data. About 23 variables were included in the analysis: nutrient concentrations (total nitrogen, nitrate nitrogen, total phosphorus, total dissolved phosphorus, ortho phosphorus, nitrogen to phospho- rus ratio), ionic concentration (alkalinity, salinity, conductivity, total suspended solids, volatile suspended solids), light (light, turbidity, Secchi depth), pesticides (alachlor, atrazine, metolochlor), $\mathrm{pH}$, dissolved oxygen, temperature, depth, and location (latitude, longitude). To equalize the range and data variability, we normalized our ecological data using Box-Cox transformation, so variables measured at different scales could contribute equally to the analysis. We used DCA to determine gradient length. By performing PCA, we identified outliers using sample scores (95\%). Lakes whose sample scores were outside the 95\% confidence intervals in both PCA and DCA were considered outliers and were omitted in the final analyses. 


\section{Results}

The Nebraska lakes are highly variable limnologically (Table 1). Natural lakes in the Nebraska Sand Hills lakes ranged from dilute freshwater (salinity $0.08 \mathrm{~g} \mathrm{l}^{-1}$ ) to hypersaline (salinity $126.85 \mathrm{~g} \mathrm{l}^{-1}$ ), while the sand pits and reservoirs are typically freshwater $\left(<0.5 \mathrm{~g} \mathrm{l}^{-1}\right)$. More than $75 \%$ of the water bodies sampled ranged in $\mathrm{pH}$ from 7.5 to 8.5 . Temperature profiles during summer months show that the natural lakes are commonly isothermal, whereas reservoirs, sand pits, and barrow pits of sufficient depth stratify during summer. Most reservoirs and Sand Hills natural lakes had high nu- trient levels. In reservoirs, watershed agricultural land use produces high nutrient concentrations, whereas in Sand Hills lakes, land-use impacts are limited, because of minimal watershed run-off. Nitrogen: phosphorus (N:P) ratios varied from 0.9 to 181; 40\% of natural lakes had $\mathrm{N}: \mathrm{P}<20$.

A PCA of environmental data for 63 lakes with complete water chemistry and geographic information (Figure 2) shows clear differences in the water chemistry of the major lake groups. The primary gradient (axis 1) is related to trophic variables, such as nutrients, light, and Secchi depth. All of the sites with high Secchi depth and low nutrient concentrations are reservoirs and sand

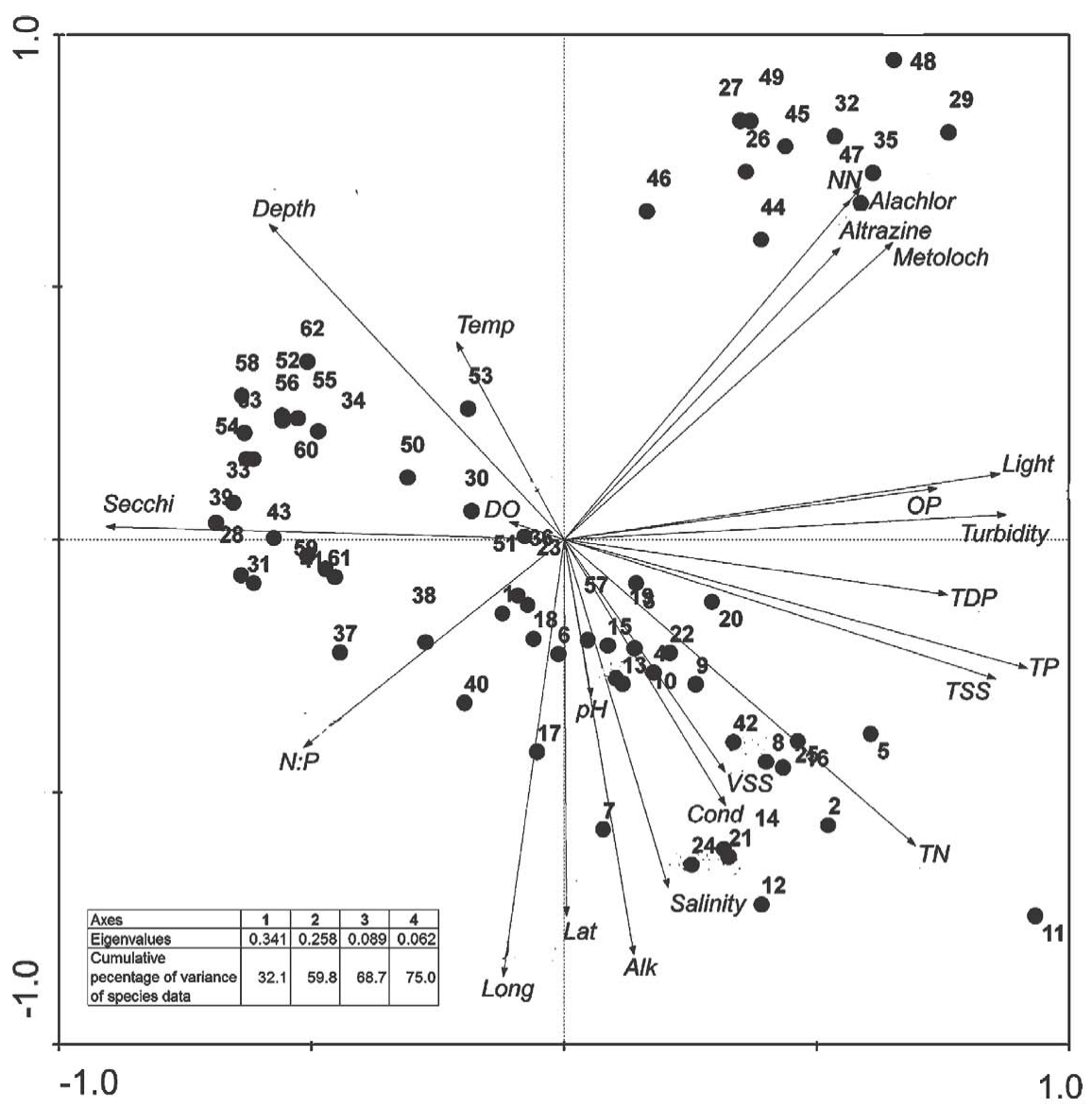

Figure 2 Principal components analysis of environmental variables from 63 natural lakes (1-25), reservoirs (26-51), and sand pits (5263). Arrows show the direction of variation of the measured environmental variables: total nitrogen (TN), nitrate nitrogen (NN), total phosphorus (TP), total dissolved phosphorus (TDP), ortho phosphorus (OP), nitrogen to phosphorus ratio (N:P), alkalinity (Alk), salinity, conductivity (Cond), total suspended solids (TSS), volatile suspended solids (VSS), light, turbidity, Secchi depth, alachlor, atrazine, metolochlor, $\mathrm{pH}$, dissolved oxygen (DO), temperature (Temp), depth, latitude (Lat), longitude (Long) 

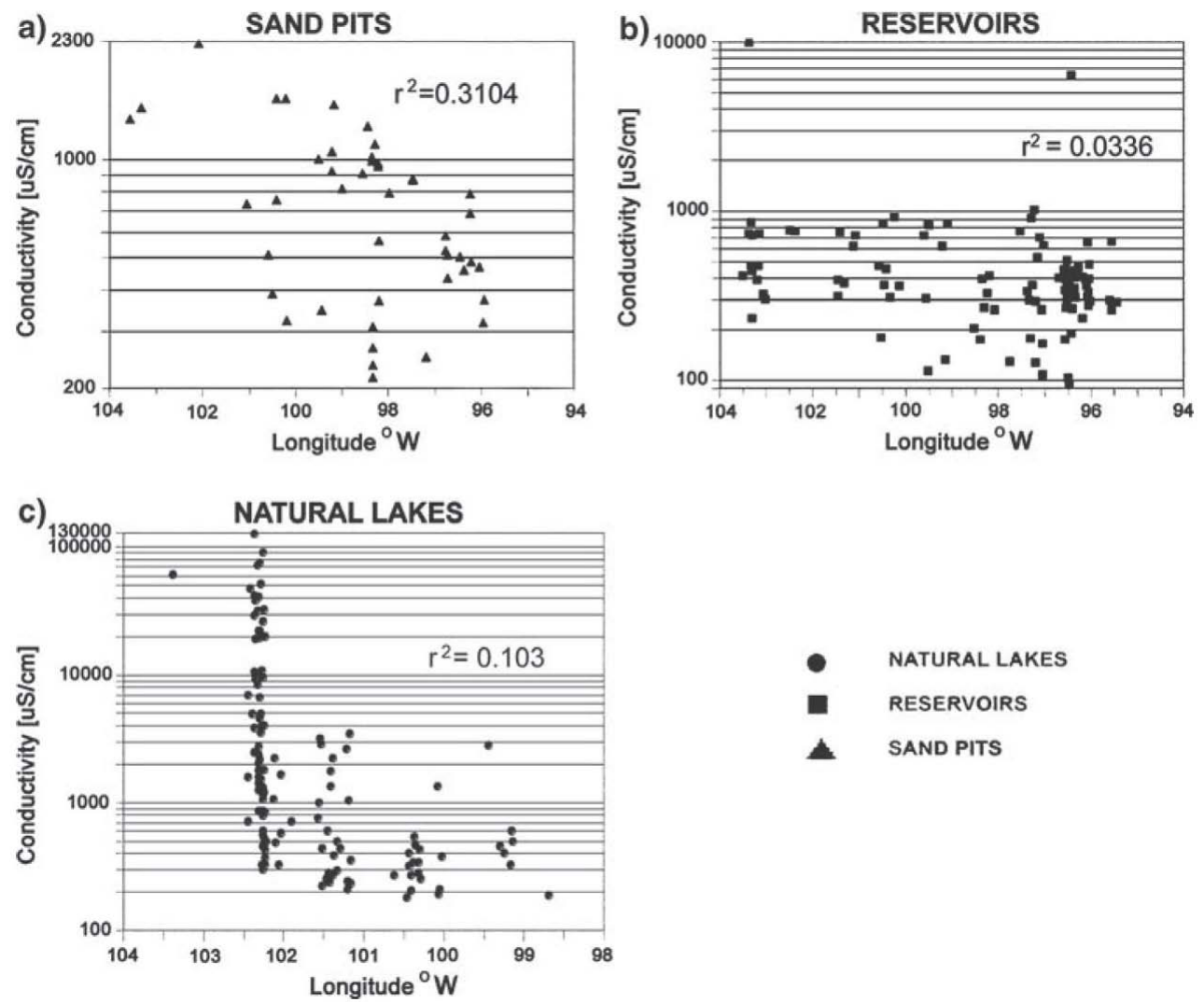

Figure 3 Conductivity versus longitude for (a) sand pits and barrow pits, (b) reservoirs, and (c) natural lakes. Each point represents the mean of all available data for the period 1989-2004

pits; some of the reservoirs and all of the natural lakes plot to the right along axis one, in association with elevated nutrient concentrations and turbidity. The second axis is a gradient associated with ionic concentration (alkalinity, conductivity, total suspended solids, salinity); all of the natural lakes are associated with high values along this gradient.

To evaluate the impact of the strong east to west moisture gradient on ion concentration, we examined the relationship between conductivity and longitude. Conductivity in sand and barrow pits increased with longitude (Figure 3a): all of the sand and barrow pits with high conductivity $(>1,000 \mu \mathrm{S})$ are in the western part of the state (west of $98^{\circ}$ ), although overall there is a wide range of chemistry at any particular longitude. No significant relationship between reservoir chemistry and location was observed (Figure
$3 \mathrm{~b})$. Although the coefficient of determination ( $r$ ${ }^{2}$ ) between conductivity and longitude is low for natural lakes, there is a clear spatial pattern. The majority of natural lakes $(92 \%)$ east of $101^{\circ} \mathrm{W}$ are fresh $(<1,000 \mu \mathrm{S})$, and all of the natural lakes

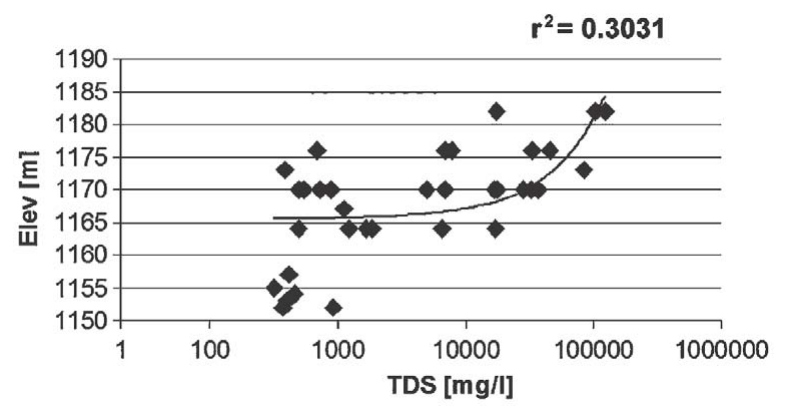

Figure 4 Relationship between lake elevation and total dissolved solids (TDS) for natural lakes in Crescent Lake National Refuge 
with high conductivity values are located in the western part of the state (Figure 3c). Within a $\sim 200 \mathrm{~km}^{2}$ area of western Nebraska, lakes with higher conductivity were located at higher elevation (Figure 4).

Seasonal measurements in natural lakes from two climatic divisions in western Nebraska (Figs. $5,6)$ showed that lake conductivity is responsive to seasonal changes in precipitation, with a gen- eral tendency of increased conductivity toward the end of the summer, consistent with observations of previous studies from this region (Gosselin, 1997). Overall lakes of higher salinity show a more consistent and predictable response to precipitation inputs, whereas the response of freshwater lakes is more variable. For example, in 1999 (Figure 5), which was moderately wet (MJJAS precipitation = $338 \mathrm{~mm}$ in division 1; $379 \mathrm{~mm}$ in division 2), con-
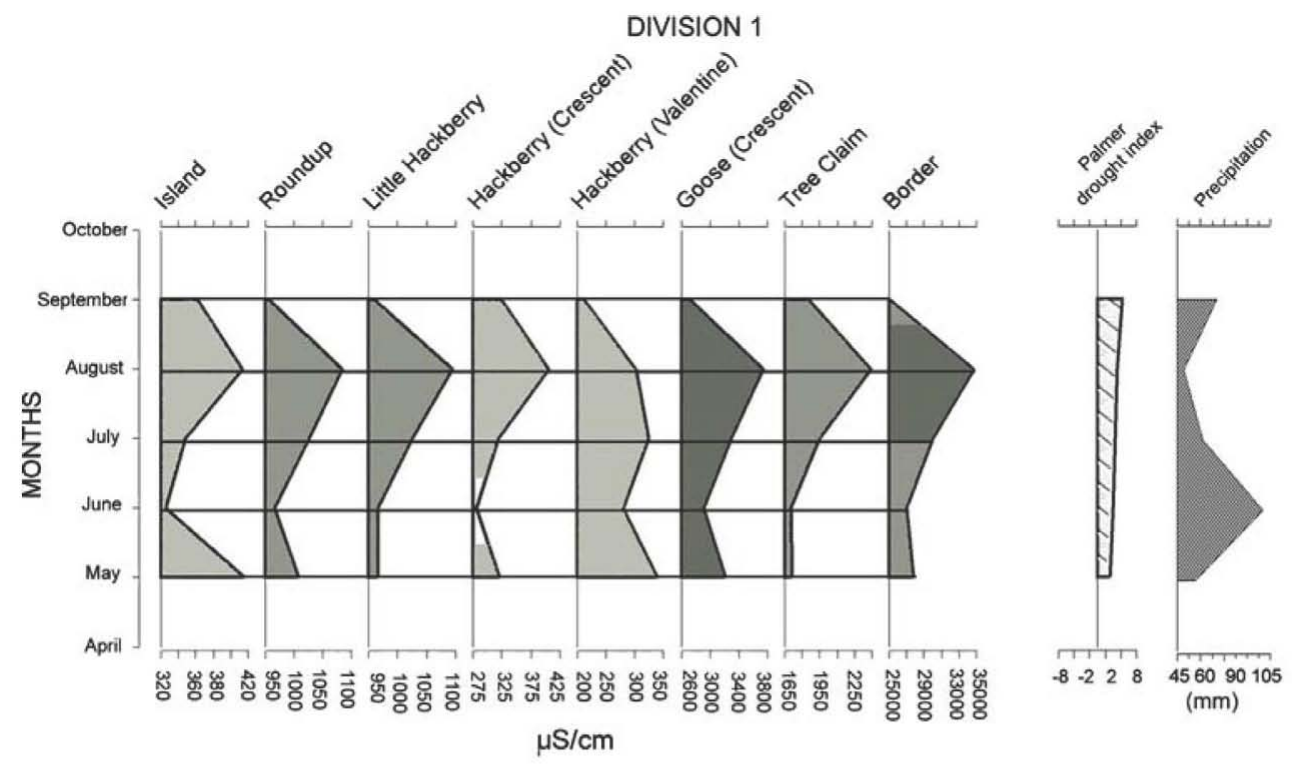

\section{DIVISION 2}

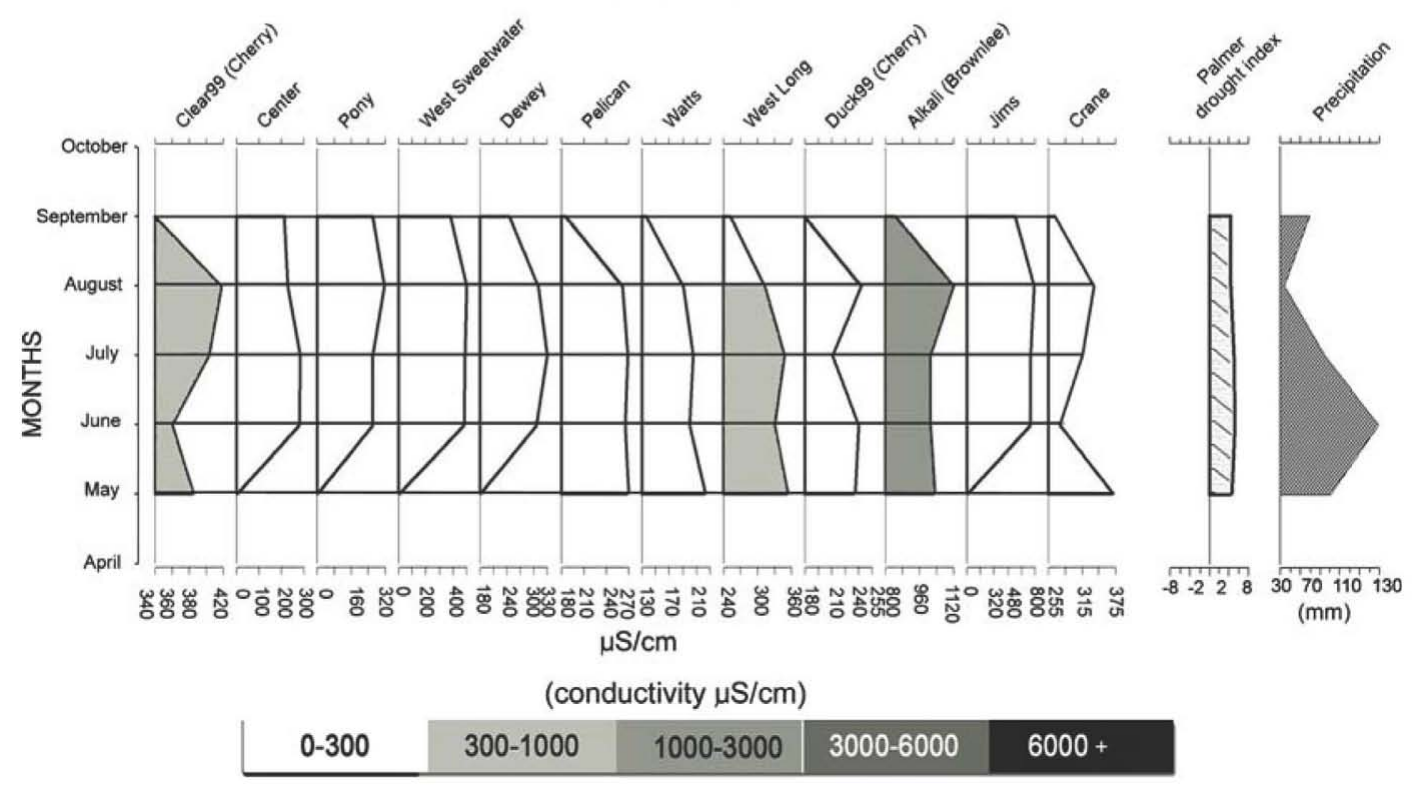

Figure 5 Monthly conductivity, Palmer drought index (PDSI monthly values), and precipitation (mm per month) for natural lakes in Climatic Divisions 1 and 2 in a moderately wet year (1999) 
ductivity decreased from May to June in the saline $\left(>3 \mathrm{~g} \mathrm{l}^{-1}\right)$ and sub-saline $\left(0.5-3.0 \mathrm{~g} \mathrm{l}^{-1}\right)$ lakes in response to increased precipitation, followed by steady or increased conductivity related to less rain in subsequent months. The response of the freshwater lakes $\left(<0.5 \mathrm{~g} \mathrm{l}^{-1}\right)$ was variable.
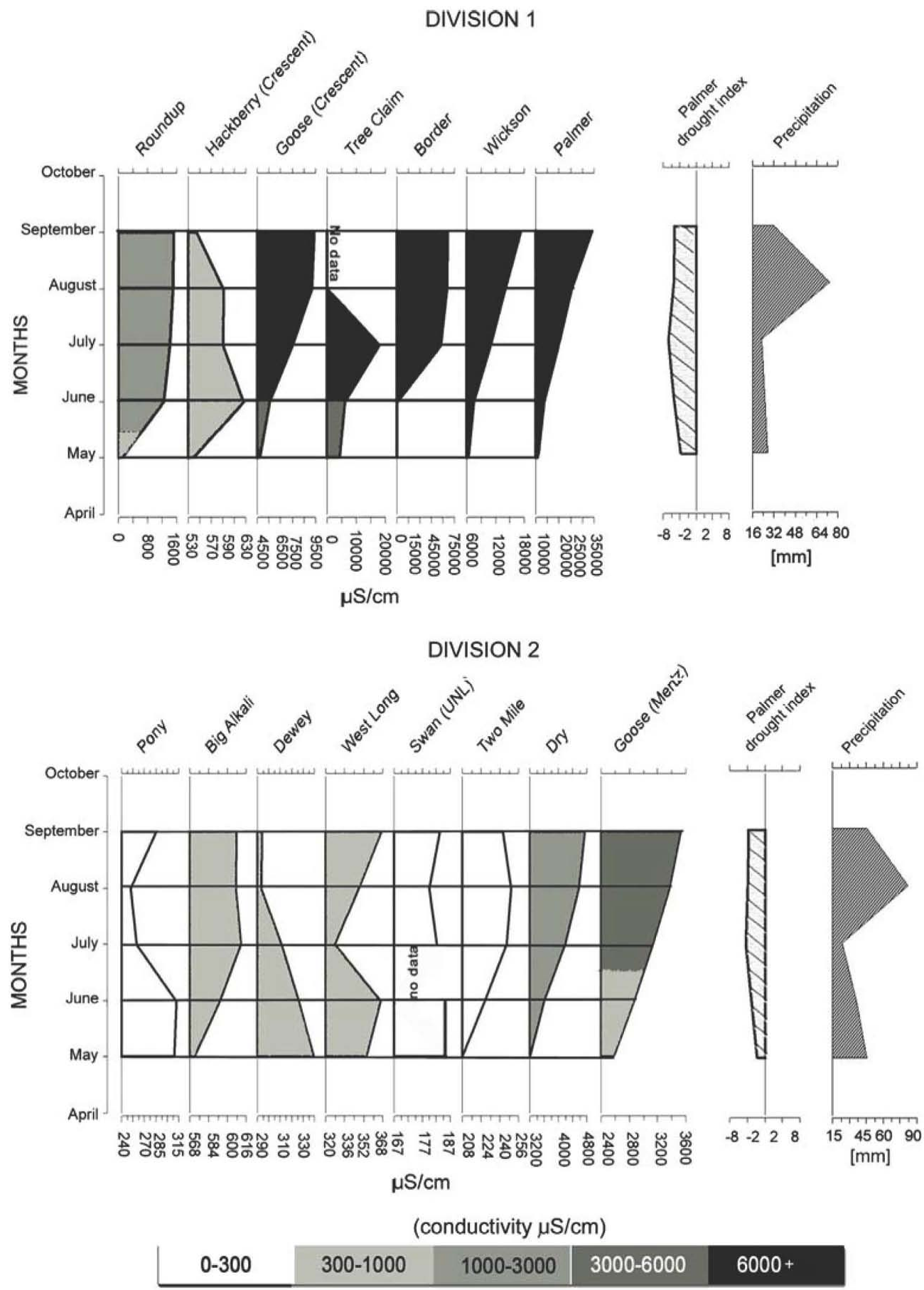

Figure 6 Monthly conductivity, Palmer drought index (PDSI monthly values), and precipitation (mm per month) for natural lakes in Climatic Divisions 1 and 2 in a dry year (2002) 
In contrast to 1999, 2002 was very dry (MJJAS precipitation $=180 \mathrm{~mm}$ in division 1,233 $\mathrm{mm}$ in division 2), and the Palmer drought severity index, which incorporates both precipitation and temperature impacts on water availability, was negative throughout the state. The dry conditions resulted in very high conductivity early in the summer at the majority of the natural lakes that were sampled and little to no conductivity change following a small increase in rain in August (Figure 6), likely because temperatures remained high. The few lakes that showed a conductivity decrease in response to the August precipitation increase (Dewey, Hackberry, and Pony) have intermittent inflow from adjoining lakes via small streams. This connectivity may increase the rate of freshwater inputs and hence the dilution of ions.

A comparison of the relationship of precipitation to conductivity in sand pits in climatic divisions 1 and 6, which span the extremes of the west to east moisture gradient, also showed clear temporal patterns (Figure 7). During the drought of 2002, the lakes in the more arid western part of the state (MJJAS precipitation $=180$ $\mathrm{mm}$ ) showed high conductivity at the onset of the spring, whereas in the eastern part (MJJAS precipitation $=389 \mathrm{~mm}$ ), lake conductivity increased as climate warmed from May to August. In both divisions, precipitation increased from August to September and consequently conductivity decreased.

Lakes in Nebraska had variable ionic composition (Figure 8), but the natural saline lakes generally were dominated by $\mathrm{Na}$ and $\mathrm{K}$, and $\mathrm{Ca}$ and $\mathrm{Mg}$ were dominant in natural and man-made freshwater lakes. Carbonate was the dominant anion in nearly all of the lakes sampled. Chloride was not dominant in any of the lakes that were studied and exceeded $10 \%$ only in one saline lake. The source of the abundant $\mathrm{Na}$ in the natural lakes is the decomposition of sodium-rich feldspars.

\section{Discussion}

Nebraska has a pronounced gradient in effective moisture (precipitation minus evapotranspira- tion) from west to east across the state, with reduced precipitation relative to evapotranspiration in the western part of the state. The impact of this gradient on lake chemistry is suggested by the association of vectors for high ionic concentration (conductivity, salinity, total suspended solids, alkalinity) and geographic parameters in the ordination of regional water-chemistry data (Figure 2). Among the man-made lakes, the east to west moisture gradient has a clear impact on the conductivity of sand and barrow pits (Figure 3a) but not on the ionic concentration of reservoirs (Figure $3 b)$. The differential sensitivity of reservoirs to the effective moisture gradient relative to sand and barrow pits is probably related to differences in the magnitude of groundwater inflow and water residence time. Thus, in reservoirs where the water budget is dominated by groundwater (in the form of river base flow) and the water residence time is short, the climatic influence is reduced.

The majority of natural lakes with high conductivity $\left(>1,000 \mathrm{~g} \mathrm{l}^{-1}\right)$ occur in the arid parts of Nebraska, and most of the eastern lakes, where precipitation is higher, are fresh (Figure 3c). The association of the natural lakes with parallel vectors of ionic concentration and longitude in the PCA (Figure 2) also suggests a significant relationship between conductivity and geographic location. Thus, across a large region, climatic impacts on ionic concentration are apparent. But within a small area of western Nebraska (Figure 4 ), the water chemistry of natural lakes is highly variable, with conductivity values that span nearly three orders of magnitude. This suggests that factors other than climate have a prominent influence on water chemistry at a local scale.

Groundwater is an important component of the water budget of some natural lakes in the region, and the magnitude and chemistry of groundwater fluxes relative to precipitation inputs may influence lake sensitivity to variability in effective moisture (Cheng \& Anderson, 1994; Webster et al., 2000). Previous studies of Sand Hills lakes have suggested that the magnitude of the groundwater inputs is a function of topography (Winter, 1986). Regional groundwater is fresh (mean TDS $477 \mathrm{mg}$ $\mathrm{l}^{-1}$, range 127-1,727 $\mathrm{mg} \mathrm{l}^{-1}$, Zlotnik et al., 2007), thus, lakes at lower elevation with larger groundwater flow-through fluxes should be fresher than 

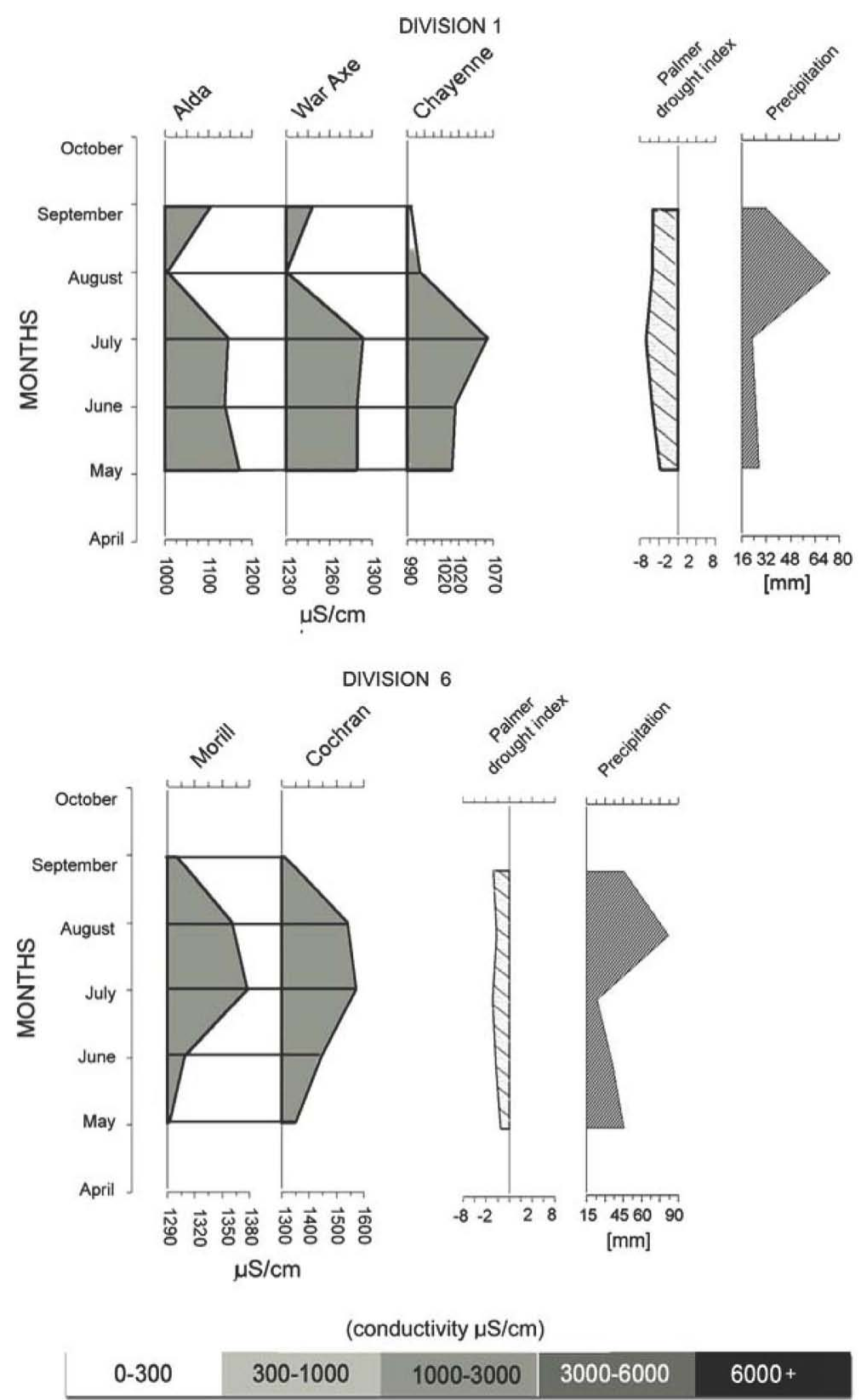

Figure 7 Monthly conductivity, Palmer drought index (PDSI monthly values), and precipitation (mm per month) of sand pits in Climatic Divisions 1 and 6 in the dry year 2002

those at high elevation. To test this hypothesis, we examined the relationship between elevation and total dissolved solids (TDS) in 25 small topographically closed natural lakes within a $15 \times 15$ $\mathrm{km}^{2}$ area within the Crescent Lake National Wildlife Refuge. In this group, lakes with higher conductivity were located at higher elevation (Figure
4), consistent with the hypothesis that ionic concentration at the local scale is strongly influenced by lake-groundwater exchanges. The variable TDS of lakes at high elevation probably reflects variable connection to the groundwater table, as well as the differential impact of evaporation in lakes of varied surface areas and volumes. 

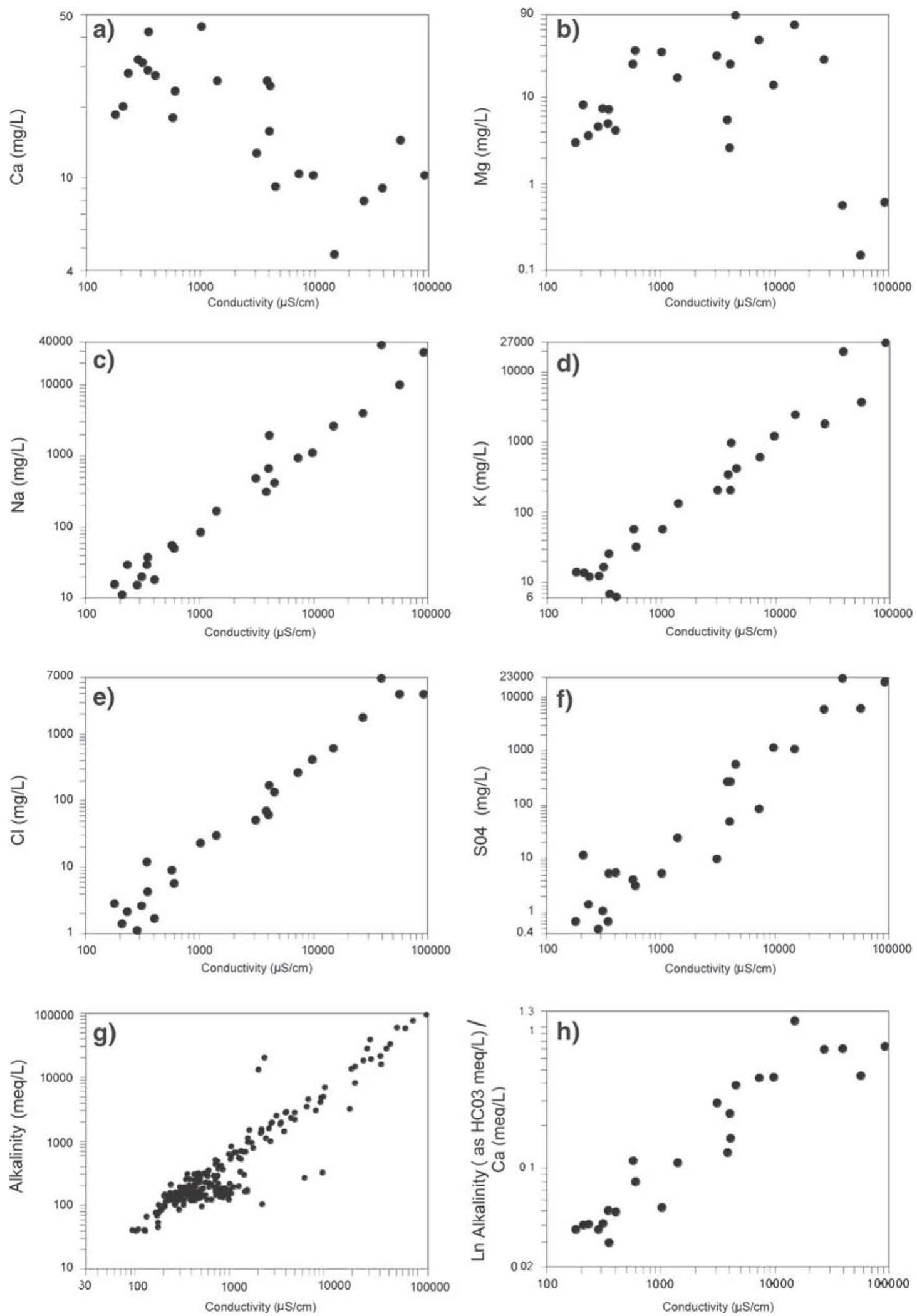

Figure 8 Relationship of major ions to conductivity in natural lakes: (a) calcium (b) magnesium, (c) sodium, (d) potassium, (e) chloride, (f) sulfate, (g) alkalinity, (h) Ln alkalinity/calcium 
Most natural lakes showed responses to seasonal changes in precipitation, with elevated conductivity following summer drought (Figs. 5-7). However, the responses among lakes with high conductivity were more uniform than among fresher lakes, likely because many of the high conductivity lakes have limited connection to groundwater flow systems. Studies of lake responses to drought in the Great Lakes region (Webster et al., 2000) also suggest more spatial heterogeneity among lakes that are groundwater dominated than among those with limited groundwater influence.

In the natural lakes of Nebraska, climate has a predictable impact on ion composition, as well as on ionic concentration. Thus, the relationship of major cation and anion concentrations along the conductivity gradient (Figure 8) is consistent with predictions based on pathways of brine evolution in response to progressive evaporative concentration (Eugster \& Jones, 1979). In regional groundwater, Ca concentrations are low relative to $\mathrm{HCO}_{3}$ (Riffenburg, 1925), and thus Ca concentrations decline at high salinity, because $\mathrm{Ca}$ is depleted during evaporation via the precipitation of calcium carbonate. Similarly, Mg concentrations are low in the most concentrated lakes. Other major ions (Na, $\mathrm{K}, \mathrm{SO}_{4}, \mathrm{Cl}$, and alkalinity) show increased concentrations as conductivity increases, because they have not been removed from solution by mineral precipitation.

This survey of spatial and temporal patterns of ionic concentration in a group of lakes that span a pronounced moisture gradient highlights the differential sensitivity of lakes to climate and the roles of both broad-scale climatic factors and of localized landscape characteristics, such as groundwater flow, in influencing the ion chemistry of lakes. Lake mean state influences the response to seasonal variation in effective moisture; thus, the responses of saline and subsaline lakes are more pronounced than those of freshwater systems. At large spatial scales, lakes with limited groundwater influence most strongly show spatially structured variation relative to gradients in effective moisture. Similarly, at small spatial scales, the nature of spatial structure in lake chemistry is related to differences in the degree of groundwater connectivity and lake morphometry. The importance of groundwater flow in modulat- ing lake response to climate also has been demonstrated for lakes in the Great Lakes region, where precipitation is considerably higher and evaporative forcing is reduced (Webster et al., 2000). The two regions provide interesting complements to one another, because of these differences in climatic setting, as well as differences in surficial geology, topographic gradients, and the chemistry of groundwater.

The results presented here have implications for paleolimnological reconstructions of drought variation, particularly in groundwater-dominated landscapes, which are common in the arid and semi-arid regions of Asia, Australia, Africa, and the Americas. In such areas, multiple sites, coupled with a clear delineation of the hydrologic setting of each basin, may be necessary to clearly reconstruct the likely causes of salinity variation through time and its climatic drivers (e.g. Fritz et al., 2000; Telford \& Lamb, 1999).

\section{Acknowledgements}

We thank J. Leach, A. Beringer, J. Swinehart, M. Burbach, and Ben Harris for assistance in the field. Supported by grants from the USEPA STAR program and The UNL Water Center (USGS Program 104B).

\section{References}

Bleed, A. \& C. Flowerday, 1998. An Atlas of the Sand Hills. Conservation and Survey Division, Institute of Agriculture and Natural Resources, University of Nebraska-Lincoln.

Cheng, X. \& M. P. Anderson, 1994. Simulating the influence of lake position on groundwater. Water Resources Research 30: 2041-2049.

Eugster, H. P. \& B. F. Jones, 1979. The behavior of major solutes during closed-basin brine evolution. American Journal of Science 279: 609-631.

Fritz, S. C. \& J. E. Saros, 2005. Paleolimnology and paleohydrology. In Anderson, M. G. (ed.), Encyclopedia of Hydrological Sciences, Vol 3: Ecological and Hydrological Interactions, Vol 3. John Wiley \& Sons, Chichester, 1681-1704.

Fritz, S. C., E. Ito, Z. Yu, K. R. Laird \& D. R. Engstrom, 2000. Hydrologic variation in the northern Great Plains during the last two millennia. Quaternary Research 53: 175-184. 
Gorham, E., W. E. Dean \& J. E. Sanger, 1983. The chemical composition of lakes in the north-central United States. Limnology and Oceanography 28: 287-301.

Gosselin, D. C., 1997. Major-ion chemistry of compositionally diverse lakes, Western Nebraska, U.S.A.: implications for paleoclimatic interpretations. Journal of Paleolimnology 17: 33-49.

Gosselin, D. C., S. Sibray \& J. Ayers, 1994. Geochemistry of K-rich alkaline, Western Sandhills, Nebraska, USA. Geochimica et Cosmochimica Acta 58: 1403-1418.

Kratz, T., K. Webster, C. Bowser, J. Magnuson \& B. Benson, 1997. The influence of landscape position on lakes in northern Wisconsin. Freshwater Biology 37: 209-217.

LaBaugh, J. W., 1986. Limnological characteristics of selected lakes in the Nebraska Sand Hills and their relation to chemical characteristics of adjacent groundwater. Journal of Hydrology 86: 279-298.

Last, W. M., 1992. Chemical composition of saline and subsaline lakes of the northern Great Plains, Western Canada. International Journal of Salt Lake Research. 1: 47-76.

Loope, D. B., J. P. Swinehart \& J. P. Mason, 1995. Dunedammed paleovalleys of the Nebraska Sand Hills-intrinsic versus climatic controls on the accumulation of the lake marsh sediments. Geological Society of American Bulletin 107: 396-406.

Mason, J. P., J. P. Swinehart \& D. Loope, 1997. Holocene history of lacustrine marsh sediments in a duneblocked drainage, Southwestern Nebraska Sand Hills, USA. The Holocene 14: 209-217.

McCarraher, B. \& D. Bruce, 1977. Nebraska’s Sandhills Lakes. In Huff, E. (ed.), Nebraska Game and Parks Commission Publisher, Lincoln, 1-67.
Riffenburg, H. B., 1925. Chemical character of ground waters of the northern Great Plains. U.S. Geological Survey Water Supply Paper 560-B: 31-52.

Schindler, D. W., S. E. Bayley, B. R. Parker, K. G. Beaty, D. R. Cruikshank, E. J. Fee, E. U. Schindler \& M. P. Stainton, 1996. The effects of climatic warming on the properties of boreal lakes and streams at the experimental lake area, northwestern Ontario. Limnology and Oceanography 41: 1004-1017.

Telford, R. J. \& H. F. Lamb, 1999. Groundwater-mediated response to Holocene climatic change recorded by the diatom stratigraphy of an Ethiopian crater lake. Quaternary Research 52: 63-75.

Webster, K. E., P. A. Soranno, S. B. Baines, T. K. Kratz, C. J. Bowser, P. J. Dillon, P. Campbell, E. J. Fee, \& R. E. Hecky, 2000. Structuring features of lake districts: landscape controls on lake chemical responses to drought. Freshwater Biology 43: 499-515.

Wilhite, D. A. \& K. G. Hubbard, 1998. Climate. In: Bleed, A. \& C. Flowerday (eds.), An Atlas of the Sand Hills. Conservation and Survey Division. University of Nebraska, Lincoln, 17-28.

Winter, T. C., 1986. Effect of groundwater recharge on configuration of the water table beneath sand dunes and on seepage lakes in the Sandhills of Nebraska, USA. Journal of Hydrology 86: 221-237.

Zlotnik, V. A., M. Burbach, J. Swinehart, D. Bennett, S. C. Fritz, D. B. Loope \& F. Olaguera, 2007. A case study of direct push methods for aquifer characterization in dune-lake environments. Environmental and Engineering Geology, in press. 